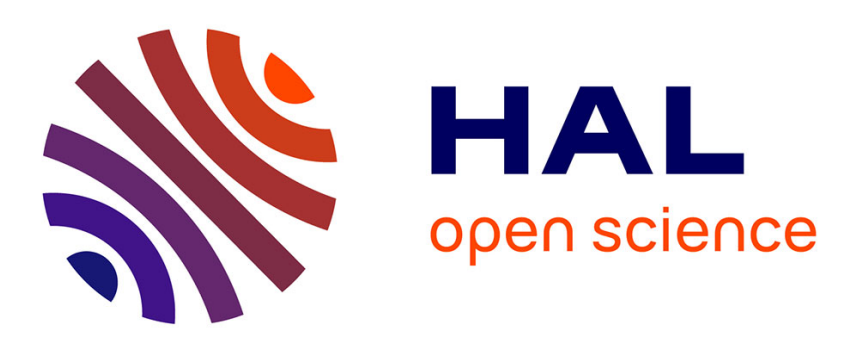

\title{
Chemotype variations among lichen ecotypes ofUmbilicaria aprinaas revealed by LC-ESI-MS/MS: a survey of antioxidant phenolics
}

\author{
Hooman Norouzi, Ali Azizi, Mansour Gholami, Mohammad Sohrabi, Joël
} Boustie

\section{To cite this version:}

Hooman Norouzi, Ali Azizi, Mansour Gholami, Mohammad Sohrabi, Joël Boustie. Chemotype variations among lichen ecotypes ofUmbilicaria aprinaas revealed by LC-ESI-MS/MS: a survey of antioxidant phenolics. Environmental Science and Pollution Research, 2020, 27 (32), pp.40296-40308. 10.1007/s11356-020-10053-2 . hal-02928572

\section{HAL Id: hal-02928572 \\ https://hal.science/hal-02928572}

Submitted on 9 Nov 2020

HAL is a multi-disciplinary open access archive for the deposit and dissemination of scientific research documents, whether they are published or not. The documents may come from teaching and research institutions in France or abroad, or from public or private research centers.
L'archive ouverte pluridisciplinaire HAL, est destinée au dépôt et à la diffusion de documents scientifiques de niveau recherche, publiés ou non, émanant des établissements d'enseignement et de recherche français ou étrangers, des laboratoires publics ou privés. 


\section{Chemotype variations among lichen ecotypes ofUmbilicaria aprinaas revealed by LC-ESI- MS/MS: a survey of antioxidant phenolics}

Hooman Norouzi ${ }^{\text {a }}$, Ali Azizi a,", Mansour Gholami ${ }^{\text {a }}$, Mohammad Sohrabi ${ }^{\text {b }}$, Joel Boustie ${ }^{c}$

a Department of Horticultural Sciences, Faculty of Agriculture, Bu-Ali Sina University, Hamedan, Iran

${ }^{\mathrm{b}}$ Department of Biotechnology, Iranian Research Organization for Science and Technology, Tehran, Iran.

${ }^{\mathrm{c}}$ Institute of Chemistry of Rennes, ISCR, UMR CNRS 6226, University of Rennes 1, 2 Av. du Pr. Leon Bernard, Rennes Cedex 35043, France

* Corresponding author:

E-mail address: azizi@basu.ac.ir

Present address: Department of Horticultural Sciences, Faculty of Agriculture, Bu-Ali Sina University, Hamedan, Iran

Telephone number: +98-81-34424192

\section{Acknowledgments}

We gratefully acknowledge the National Elites Foundation of Presidency of the Islamic Republic of Iran for the financial support. We are also grateful to Dr. Seyyed Reza Safavi (Research Institute of Forests and Rangelands of Iran) and Dr. Hossein Rezvan (Bu Ali Sina University) for their valuable technical assistance. 


\begin{abstract}
In the present study, we characterized the phytochemical profile of six distinct ecotypes of Umbilicaria aprina Nyl. from Iran (include: Kivarestan, Mishan, Takht-e Nader, Tochal, Sabalan, and Sahand ecotypes) in order to ascertain whether the environmental differences can affect the chemical profile of this species. Based on the results of LC-ESI-MS/MS, 9 major chemical substances were identified: Orsellinic acid (1), Lecanoric acid (2), Evernic acid (3), Gyrophoric acid (4), Umbilicaric acid (5), Hiascic acid (6), Stictic acid (7), a member of Hiascic acid complex (8), and an unknown substance (9). The MS/MS fragmentation patterns of each substance were determined and proposed. Broad variability was observed in the chemical profiles of lichen samples according to the presence/absence of these substances. The results corroborate that the influence of ecological locality conditions for example altitude, slope aspect, light intensity, and temperature, on phytochemical variations among ecotypes of a particular lichen species like $U$. aprina are of great importance.
\end{abstract}

Keywords: Umbilicaria aprina, Umbilicariaceae, phytochemical profile, LC-ESI-MS/MS, Fragmentation pattern, Depsides, ecological factors, slope aspect 


\section{Introduction}

Lichen, as a form of mutualistic symbiosis life between algae/cyanobacteria (as photobiont/cyanobiont) and fungi (as mycobiont), is one of the biotechnological interesting issues that attracted much consideration due to its potential for producing multifarious pharmaceutical secondary metabolites especially phenolics such as depsides, depsidones and depsones which are specifically originating from the mycobiont (Oettl et al., 2014).

Depsides, such as Gyrophoric acid, umbilicaric acid, and lecanoric acid, which are the eventual products of esterification of orcinol rings through acetyl polymalonyl pathway are mainly produced by most species of family Umbilicariaceae (Nguyen et al., 2013; Oettl et al., 2014; Ranković, 2015). Many studies have demonstrated the presence of high concentrations of phenolic compounds in different Umbilicaria species (Fernández-Moriano et al., 2016).

The family Umbilicariaceae contains two main genera, Lasallia and Umbilicaria. In accordance with climatic conditions in Iran, the genus Lasallia is not a member of the lichen flora of this country, but the Umbilicaria as a worldwide boreal and sub-boreal genus occurs chiefly in alpine zones of Iran. According to the latest checklist of lichen flora in Iran published by Seaward et al. (2008) the genus Umbilicaria has 11 distinguished species in Iran including U. aprina, U. cinerascens, U. cinereorufescens, U. cylindrica, $U$. decussata, U. freyi, U. hirsuta, U. microphylla, U. nylanderiana, U. polyphylla and U. vellea. Among the mentioned species, the $U$. aprina is a highly distributed species in alpine regions of Iran.

Phytochemical analysis of Umbilicaria species by several authors, has revealed the presence of ca. 16 compounds including gyrophoric acid, lecanoric acid, umbilicaric acid, hiascic acid, ovoic acid, crustinic acid, lasallic acid, usnic acid, norstictic acid, salazinic acid, atraric acid, atranorin, unknown terpenoids, methyl orsellinate, methyl $\beta$-orcinolcarboxylate and ethyl hematomate (Hestmark, 1991; Krog and Swinscow, 1986; Krzewicka, 2004; Krzewicka and Osyczka, 2002; Manojlović et al., 2012; Narui et al., 1998, 1996; Poelt and Nash, 2006; Posner et al., 1992; Serina et al., 1996; Zlatanović et al., 2017).

Despite the wide distribution of $U$. aprina throughout the world, there isn't any clear report about its phytochemical profile. Based on thin-layer chromatography (TLC) results in few studies (Hestmark, 1991; Krog and Swinscow, 1986; Krzewicka, 2004; Krzewicka and Smykla, 2004), the major secondary product in U. aprina is gyrophoric acid which is always accompanied by lecanoric acid. Therefore, gyrophoric acid and lecanoric acid are the only reported secondary substances from $U$. aprina up to now.

On the other hand, qualitative and quantitative polymorphism of secondary metabolites is expected in various ecotypes of a particular species due to geographical distribution according to results of several studies 
(Bjerke et al., 2005, 2003; Culberson, 1967; Fahselt and BeGora, 2001; Piercey-Normore, 2007, 2003). Whereas $U$. aprina is a widespread species in Iran, we can anticipate certain phytochemical variations between different ecotypes of this species.

The purpose of this study was to investigate the discrepancies between qualitative phytochemical profiles of various $U$. aprina ecotypes distributed throughout the boreal regions of Iran, in order to confirm the role of ecology in imposing alterations on phytochemical traits of lichens. To the best of our knowledge, liquid chromatography (LC) coupled with electrospray ionization tandem mass spectrometry (ESI-MS/MS), is a reliable analytical method, applicable for accurate identification and quantification of lichen secondary metabolites. Therefore, in this study, an attempt was made to determine the individual phenolic compounds of six $U$. aprina ecotypes from Iran, for the first time based on LC-ESI-MS/MS.

\section{Experimental}

\subsection{Chemicals and reagents}

All the commercial chemicals and reagents including analytical acetone for extraction, LC-MS grade water, acetonitrile, and formic acid were purchased from Merck (Germany).

\subsection{Lichen material}

Thalli of $U$. aprina ecotypes were collected from siliceous alpine rock surfaces on six different alpine zones of Iran during May and June 2018. According to table 1, three ecotypes were collected from Alvand Mt. in Hamadan province (Kivarestan, Takht-e Nader, Mishan), one ecotype from Tochal Mt. in Tehran province (Tochal), one ecotype from Sabalan Mt. in Ardabil province (Sabalan) and one ecotype was collected from Sahand Mt. in East Azerbaijan province (Sahand). After cleaning, the sample identification was substantiated by data from examinations of macroscopic, microscopic and chemical (thalline reaction with para-phenylenediamine $(\mathrm{P})$, potassium hydroxide $(\mathrm{K})$ and sodium hypochlorite $(\mathrm{C})$ or/and $\mathrm{KC}$ reagents) characters and ultimately by comparison with the literature. Voucher specimens for each ecotype were deposited at ICH lichen herbarium of Iranian research organization for science and technology (IROST), and their identity was confirmed by Dr. Mohammad Sohrabi. The thalli were air-dried for one week in room temperature and then grounded to a fine powder using pestle and mortar under liquid nitrogen and stored at room temperature in closed tubes. 


\subsection{Sample preparation}

An extraction of $5 \mathrm{~g}$ dry $U$. aprina powder for each ecotype was performed in $50 \mathrm{~mL}$ of acetone in an ultrasonic bath during 30 minutes in $20^{\circ} \mathrm{C}$. The extracts were filtered (Whatman filter paper grade 2) and then concentrated under reduced pressure in a rotary evaporator. The dry extracts of ecotypes were stored at $-20^{\circ} \mathrm{C}$ until they were used for phytochemical screening.

\subsection{LC-ESI-MS/MS analysis}

The chromatographic analyses of lichen compounds were conducted on a Waters Alliance e2695 separation module (Waters Corporation, Milford, MA, USA) through an Atlantis T3 C18 column $(2.1 \mathrm{~mm} \times 100$ $\mathrm{mm}, 3 \mu \mathrm{m}$; Waters Corp., Milford, MA, USA) which was kept at $30^{\circ} \mathrm{C}$. The MS/MS spectra were acquired from a Quattro micro API mass spectrometer (Waters Corp., Milford, MA, USA) equipped with an ESI source. Immediately before analysis, $5 \mathrm{mg}$ of the dry residue of the extract was dissolved in $5 \mathrm{~mL}$ methanol. Then, the samples were filtered through PTFE membrane filters (pore size $0.45 \mu \mathrm{m}$, Simplepure, China). Chromatographic separations were performed at a flow rate of $0.25 \mathrm{ml} / \mathrm{min}$ using a gradient elution program starting from $95 \%$ of eluent A (water with $0.1 \%$ formic acid, v/v) and gradually changing to $5 \%$ A over $20 \mathrm{~min}$. Elution was continued for $5 \mathrm{~min}$ by $95 \%$ of eluent B (acetonitrile). This allowed elution of all analytes within 25 minutes. The injection volume was $10 \mu \mathrm{L}$.

Mass detection conditions were as follows: source temperature $120^{\circ} \mathrm{C}$, desolvation temperature $300^{\circ} \mathrm{C}$, capillary voltage $3.5 \mathrm{kV}$, cone voltage $30 \mathrm{~V}$. Nitrogen was used for both nebulizing and drying the gas. The samples were measured in negative ionization mode and scanned in the range of $50-600 \mathrm{~m} / \mathrm{z}$. The MS/MS analyses were performed with the collision energy of $30 \mathrm{eV}$. The MassLynx V 4.1 software (Waters) was used for the data evaluation.

\subsection{Aspect map}

For generating the aspect map of Iran and study areas we used topographic data of Iran provided by ArcGIS Online. Using ArcGIS (ArcMap) 10.6.1 software we could convert the topographic data to digital elevation map (DEM). Spatial analyst tools were used for engendering the aspect map of Iran from DEM.

\section{Results and discussion}

\subsection{LC-ESI-MS/MS peak identification and fragmentation pathways}


In the present study detection of 9 major compounds eventuated from qualitative analysis of the phytochemical profile of six $U$. aprina ecotypes using LC-ESI-MS/MS in negative ion mode (Table 2). The identification of major compounds was facilitated by their MS/MS spectra and comparison to literature. Major compounds identified in this species were mainly depsides, depsidones, and monocyclic aromatic compounds.

One monocyclic aromatic compound was identified based on its $\mathrm{MS}^{2}$ spectra. Peak 1 was detected as orsellinic acid which indicated an $[\mathrm{M}-\mathrm{H}]^{-}$ion at $\mathrm{m} / \mathrm{z} 167.210$ whose cleavage produced 2 perceptible $\mathrm{MS}^{2}$ ions at $m / z 81.385$ and $\ldots . .$. Our results are in great accordance with those reported by other authors (Brakni et al., 2018; Castro et al., 2017; Kumar et al., 2018; Musharraf et al., 2015; Parrot et al., 2015; Torres-Benítez et al., 2017).

Five depsides were identified using $\mathrm{MS}^{2}$ analysis. Peak 3 was identified as umbilicaric acid whose molecular ion was detected at $m / z$ 481.646. Major observable daughter $\mathrm{MS}^{2}$ ions of umbilicaric acid were detected at $\mathrm{m} / \mathrm{z} 181.050,167.075,162.810,148.882$ and 136.950. Although umbilicaric acid is a well-known tridepside, its negative ion mode mass fragmentation pathway has not been reported up to now. Here we have proposed a cleavage pathway for umbilicaric acid in Fig 1. The cleavage of ester bonds between aromatic units leads to the generation of representative $\mathrm{MS}^{2}$ ions at $m / z$ 181.050, 167.075 and 148.882. Separation of $\mathrm{CO}_{2}$ and $\mathrm{H}_{2} \mathrm{O}$ from $\mathrm{m} / \mathrm{z}$ 181.050 and 167.075 results in other $\mathrm{MS}^{2}$ fragments for umbilicaric acid at $\mathrm{m} / \mathrm{z}, 136.950$ and 148.882 . Peak 4 indicated a molecular ion at $m / z 331.398$ which was identified as evernic acid on the basis of its diagnostic MS $^{2}$ daughter ions at $m / z 180.952,162.723,148.915,136.915$ and 104.848. . Our results for Evernic acid are in suitable concordance with other researches (Brakni et al., 2018; Castro et al., 2017; Jin et al., 2018; Torres-Benítez et al., 2017). A molecular ion at $\mathrm{m} / \mathrm{z} 483.702$ was detected for peak 4 which made the identification of hiascic acid feasible for us by the production of four cleaved diagnostic $\mathrm{MS}^{2}$ ions at $\mathrm{m} / \mathrm{z} 183.005,166.974,148.910$ and 122.840. This is the first report on hiascic acid identification by means of MS fragmentation pattern in negative ion mode, therefore we deduced a reasonable fragmentation pathway for this tridepside in Fig 2. The most prevalent fragmentation pattern for tridepsides is the separation of aromatic units due to ester bond cleavage and there is no exception in the case of hiascic acid. Thus, 3 representative $\mathrm{MS}^{2}$ ions at $\mathrm{m} / \mathrm{z} 183.005,166.974$ and 148.910 are results of ester bonds cleavage. Further losses such as $\mathrm{CO}_{2}$ and $\mathrm{H}_{2} \mathrm{O}$ from $\mathrm{m} / \mathrm{z}, 166.974$ ion leads to $\mathrm{MS}^{2}$ fragments at $\mathrm{m} / \mathrm{z}, 148.910$ and 122.840. Peak 5, indicated a deprotonated molecular ion at $\mathrm{m} / \mathrm{z} 497.736 \mathrm{which}$ was identified as a member of the hiascic acid complex on the basis of its fragmentation pattern with 3 representative $\mathrm{MS}^{2}$ ions at $\mathrm{m} / z, 196.962,152.860$ and 108.898. There are 3 compounds with the same molecular ion mass in hiascic acid complex including 2-O-Methylhiascic acid, 4-O-Methylhiascic acid, and 5-OMethylhiascic acid and the main difference between these 3 compounds is the situation of the methyl group on 
ring $\mathrm{A}$, therefore all we could determine was that the ion at $\mathrm{m} / \mathrm{z}, 497.736$ is a member of the hiascic acid complex. As we have proposed in Fig 3 separation of ring A leads to an ion at $m / z 196.962$ and loss of a $\mathrm{CO}_{2}$ from this fragment results in an ion at $m / z$ 152.860. Further separation of rings B and C provides other ions. The aromatic ring $\mathrm{C}$ produces 2 other diagnostic $\mathrm{MS}^{2}$ fragments at $\mathrm{m} / z, 152.860$ and 108.898 through the loss of methyl and a $\mathrm{CO}_{2}$ respectively. Peak 6 demonstrated a molecular ion at $m / z 317.400$ which is characteristic of lecanoric acid. We observed 3 representative ions at $\mathrm{m} / \mathrm{z}, 166.970,148.920$ and 122.883 which facilitated the identification of lecanoric acid for us. These results for lecanoric acid are in great conformity with those from other studies (Brakni et al., 2018; Castro et al., 2017; Kumar et al., 2018; Musharraf et al., 2017, 2015; Parrot et al., 2015; Salgado et al., 2018; Torres-Benítez et al., 2017). Peak 7 as gyrophoric acid was detected at $\mathrm{m} / \mathrm{z}$ 467.612. Precise investigation of its cleavage pattern resulted in recognition of 3 major $\mathrm{MS}^{2}$ ions at $m / z 166.949,148.912$ and 122.920. A proportionate correspondence was observed between our findings and other studies (Castro et al., 2017; Cornejo et al., 2016; Kumar et al., 2018; Musharraf et al., 2015; Salgado et al., 2018; Torres-Benítez et al., 2017).

Peak 2 represented a molecular ion at $m / z 385.419$ whose $\mathrm{MS}^{2}$ analysis revealed 3 diagnostic fragments at $m / z$ 167.020, 148.932 and 122.950. These $\mathrm{MS}^{2}$ ions are correspondent to those of stictic acid, therefore peak 2 was identified as the stictic acid, which is a depsidone. Our proposed fragmentation pattern for stictic acid in Fig 4 does not conform well to findings from other studies (Kumar et al., 2018; Matteucci et al., 2017; Parrot et al., 2013; Salgado et al., 2018; Torres-Benítez et al., 2017; Xu et al., 2017). Generally, after $\mathrm{CO}_{2}$ separation from the molecular ion $([\mathrm{M}-\mathrm{H}]=385.419)$, a fragment will appear at $\mathrm{m} / z .341 .07$ whose cleavage results in the production of 2 fragments at $m / z 148.932$ and 196.04. The detachment of $\mathrm{CH}_{2} \mathrm{O}$ from the latter generates an ion at $\mathrm{m} / z 167.020$ and further loss of $\mathrm{CO}_{2}$ from this ion brings forth another fragment at $\mathrm{m} / \mathrm{z} 122.950$.

In this study, we have detected gyrophoric acid and lecanoric acid in all the investigated ecotypes of $U$. aprina (Table 2). Orsellinic acid, umbilicaric acid, hiascic acid and the member of the hiascic acid complex were also figured out in all the ecotypes. Gyrophoric acid, lecanoric acid, umbilicaric acid, and norstictic acid are the most prevalent lichen substances in genus Umbilicaria (Serina et al., 1996). Gyrophoric acid is the most prominent secondary metabolite in Umbilicaria genus, commonly accompanied by lecanoric acid as a concomitant compound in lower concentrations (Posner et al., 1992). An informative result reported by Serina et al (1996) is the coincidence of gyrophoric acid and hiascic acid in their samples, so the co-occurrence of these two tridepsides in our investigated ecotypes was plausible. Based on the literature (Hestmark, 1991; Krog and Swinscow, 1986; Krzewicka, 2004; Krzewicka and Osyczka, 2002; Manojlović et al., 2012; Narui et al., 1998, 1996; Poelt and 
Nash, 2006; Posner et al., 1992; Serina et al., 1996; Upreti and Pant, 2008; Zlatanović et al., 2017) presence of umbilicaric acid in all of the U. aprina ecotypes is also admissible.

Orsellinic acid as a monocyclic aromatic compound, evernic acid as a depside and the member of hiascic acid complex as a tridepside are secondary metabolites detected in this study and they have not been reported from Umbilicaria to date. Posner et al (1992), emphasized the systematic significance of stictic acid or norstictic acid in Umbilicaria species and they ascertained the presence of stictic acid in $U$. torrefacta and here we detected the presence of stictic acid in U. aprina for the first time.

\section{2. phytochemical discrepancies between ecotypes}

In this study, Kivarestan, Tochal, and Sahand ecotypes indicated a similar secondary metabolite profile and we could elucidate their compounds as orsellinic acid, stictic acid, umbilicaric acid, hiascic acid, putative hiascic acid complex member, lecanoric acid and gyrophoric acid on the basis of their MS/MS spectra and fragmentation patterns (Table 2). Sabalan ecotype showed the same secondary metabolites with foresaid ecotypes but it lacked stictic acid. For Takht-e Nader ecotype an unknown compound was observed at $m / z, 347.400$ we could not identify, however ignoring this extra substance, the secondary metabolite pattern for this ecotype showed similarities with Kivarestan, Tochal and Sahand ecotypes (Table 2). Mishan ecotype indicated the most multifarious metabolic profile by the presence of two extra substances including evernic acid and an unknown compound at $m / z 347.400$ while it lacked stictic acid (Table 2).

Qualitative differences (e.g. presence or absence of a particular compound) in the phytochemical profile of some ecotypes, for example, absence of stictic acid in Mishan and Sabalan ecotypes or existence of evernic acid and an unknown compound in Mishan ecotype (Table 2) can be justified as a type of quantitative variation. Presence or absence of a specific compound, or at least our inability in detecting that particular compound, may be related to a status of drastic quantitative fluctuation i.e. the concentration of that compound have endured intense fluctuations in a way that we can't detect it readily with the aid of common approaches. The prominent example of such condition in our study is stictic acid. Fahselt (2008), on the basis of results from previous studies by Clayden (1992) and Culberson et al. (1993) (Clayden, 1992; Culberson et al., 1993), emphasizes on downregulation of synthetic enzymes or significant attenuating changes in coding regions which can result in severe quantitative fluctuations. Such chemical plasticity is a considerable strategic reaction of lichens to different ecological zones. It is substantiated by data from number of studies that secondary metabolite fluctuations in thalli of lichens, especially in ecotypes of a particular species, can be affected by various environmental factors such as 
allelopathy (Fahselt, 2008), geographical distribution (Bjerke et al., 2005; Culberson, 1967; Piercey-Normore, 2007, 2003), light and UV intensity (Rubio et al., 2009), habitat elevation (Shukla et al., 2016; Swanson et al., 1996), seasonality (Ranković and Kosanić, 2015) and temperature oscillations (Bjerke et al., 2003; Culberson et al., 1983; Hamada, 1991, 1984, 1982). Therefore, we expect phytochemical alterations in a specific impressionable species under various climatic conditions.

Due to its preference, $U$. aprina grows mostly in elevated alpine habitats, where the distinguishing characteristic of the environment is the labile climatic condition which predispose $U$. aprina ecotypes to various sequential abiotic stresses. Among all factors Altitude, light intensity and moisture might be the most effective driving forces in changing the chemical profile of lichens. As the radiation intensity can be affected by the topographic factors like slope aspect on which the lichen is growing, we can consider an important role for the efficacy of this factor (Shukla et al., 2016). Moreover, the intensity of radiation can modify the amount of moisture in a particular locality. Despite the limited distance between Takht-e Nader, Mishan and Kivarestan ecotypes, certain qualitative chemical differences were observed between them. The two main differences between the localities of these three ecotypes were the altitude and the slope aspect on which they were growing. The aspect map of the Takht-e Nader, Mishan and Kivarestan ecotypes are presented in Fig 5. The localities of Takht-e Nader and Kivarestan ecotypes are both southeast-facing while locality of Mishan ecotype is east-facing which can modify the intensity of radiation for each ecotype. Moreover, there is tangible difference between the locality altitude of these three ecotypes (Table 1) as if the locality of Kivarestan ecotype lies in a lower altitude (2449 m) and the elevation rises for localities of Mishan $(2691 \mathrm{~m})$ and Takht-e Nader $(3028 \mathrm{~m})$ ecotypes. The rise in elevation can result in different temperatures and UV intensity for each locality. As we can see in Fig. 11, locality of the Tochal ecotype lies on a south-facing aspect which means that this locality receives much more direct radiation compared with a locality which is lied on a north-facing aspect like the one for Sabalan ecotype. The locality of Sahand ecotype shows a southwest-facing aspect. According to Fig 5, it seems that the only southfacing localities belong to Tochal and Sahand ecotypes and therefore they might have received much more direct radiation compared to other ecotypes. Therefore, it might be possible that ecotypes with more similar slope aspect indicate much more resembling chemical profiles. Since the localities of Sabalan and Mishan ecotypes are likely to receive lower intensities of direct radiation maybe we could consider this factor as a reason for lack of the Stictic acid in both of these ecotypes. Moreover, Sabalan ecotype belongs to a geographical region that long periods of cold and frigidity pervades the area for most of the year, therefore this persistent freezing state may influence the quality of chemical profile in Sabalan ecotype. Accordingly, the variation of chemical profile of our 
investigated ecotypes may be attributable to all these environmental and topographic differences between their localities.

Based on our results in this study, which indicated differences between phytochemical profiles of investigated $U$. aprina ecotypes (Table 2), and also results from previously mentioned studies, perhaps we could ascribe such phytochemical variations to the effect of a set of environmental and endo-lichenic interactions that lead to suppression or increase in expression of some genes that subsequently affects the activity of certain enzymes in the biosynthetic pathway of various compounds.

\section{Conclusions}

A phytochemical analysis including metabolic profiling of six $U$. aprina ecotypes was performed in this study. To the best of our knowledge, this study represents the first metabolic profiling of $U$. aprina making use of LC-ESI-MS/MS approach which resulted in identification of 9 major secondary metabolites (orsellinic acid, umbilicaric acid, evernic acid, stictic acid, hiascic acid, hiascic acid complex member, lecanoric acid, gyrophoric acid and an unknown compound), mainly on the basis of their fragmentation patterns. Cleavage pathways are proposed for umbilicaric acid, hiascic acid and hiascic acid complex member for the first time. Certain ecotypes were indicated to have similarities in chemical profile but there were also considerable variations between them. Orsellinic acid, umbilicaric acid, hiascic acid, hiascic acid complex member, lecanoric acid and gyrophoric acid were ubiquitous compounds as if they were detected in all the investigated ecotypes, but the majority of differences between ecotypes can best be elucidated by presence or absence of stictic acid, evernic acid, and an unknown compound. Perhaps these 3 compounds are the key secondary metabolites for $U$. aprina's chemotaxonomy. The most diverse metabolic profile was detected for the Mishan ecotype which indicated the presence of 8 out of 9 identified compounds.

Phytochemical differences revealed in this study, suggest that a particular lichen species, like U. aprina in our study, possess potent sentience which enables them to perceive the changes in environmental factors and geographical distribution. Based on the variations described previously, we can assert that ecological differences impose alterations on the metabolic profile of $U$. aprina but we need to study the effect of different environmental factors and also genetic variabilities between ecotypes so that the main reason for chemical differences will be clearly established. Moreover, the structure and nature of the unknown compound at $\mathrm{m} / \mathrm{z}, 347.020$ remain to be studied by accurate approaches. 
Table 1

Lichen material investigated in this study: details of collection sites

\begin{tabular}{c|l|c|l|c}
\hline \multicolumn{2}{c|}{ U. aprina ecotype } & $\begin{array}{l}\text { Voucher } \\
\text { No. }\end{array}$ & $\begin{array}{l}\text { GPS coordinates of } \\
\text { localities }\end{array}$ & Altitude $^{\text {a }}$ \\
\hline 1 & Kivarestan & 18723 & 34.759 N 48.432 E & 2449 \\
2 & Takht-e Nader & 18755 & 34.769 N 48.409 E & 3028 \\
3 & Mishan & 18759 & 34.768 N 48.426 E & 2691 \\
4 & Tochal & 18731 & 35.858 N 51.396 E & 3070 \\
5 & Sabalan & 18740 & 38.321 N 47.845 E & 3032 \\
6 & Sahand & 18750 & 37.610 N 46.417 E & 3032 \\
\hline
\end{tabular}

${ }^{a}$ Altitude expressed in meters above sea level 


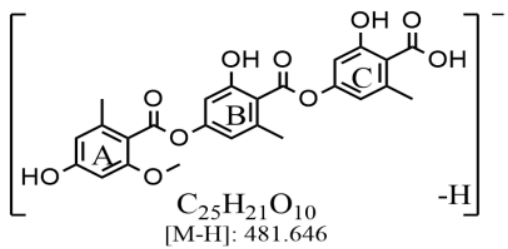

[M-H]: 481.646

Ester bonds cleavage
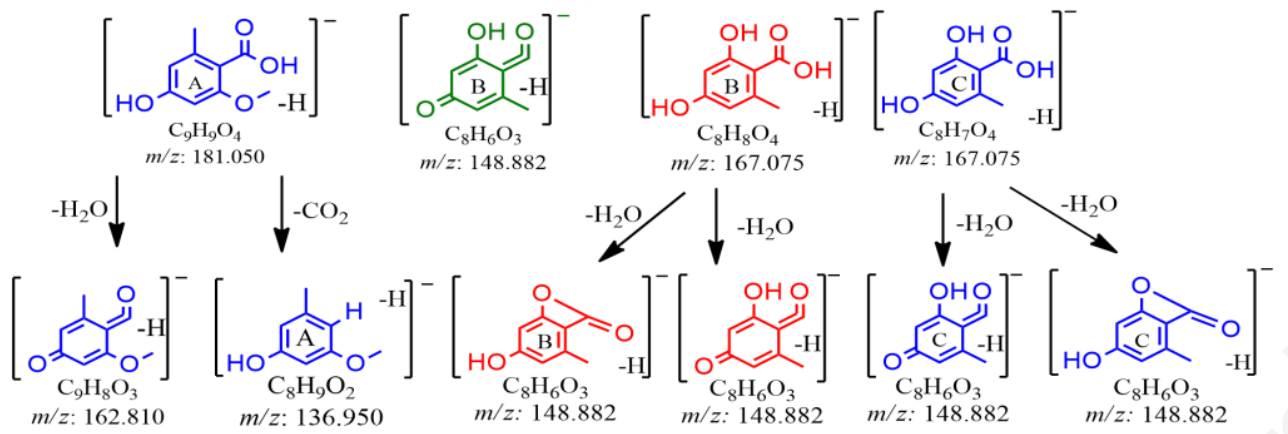

$\mathrm{m} / \mathrm{z}: 148.882$

$m / z: 167.075$

$m / z: 167.075$

Fig 1 Proposed fragmentation scheme of umbilicaric acid

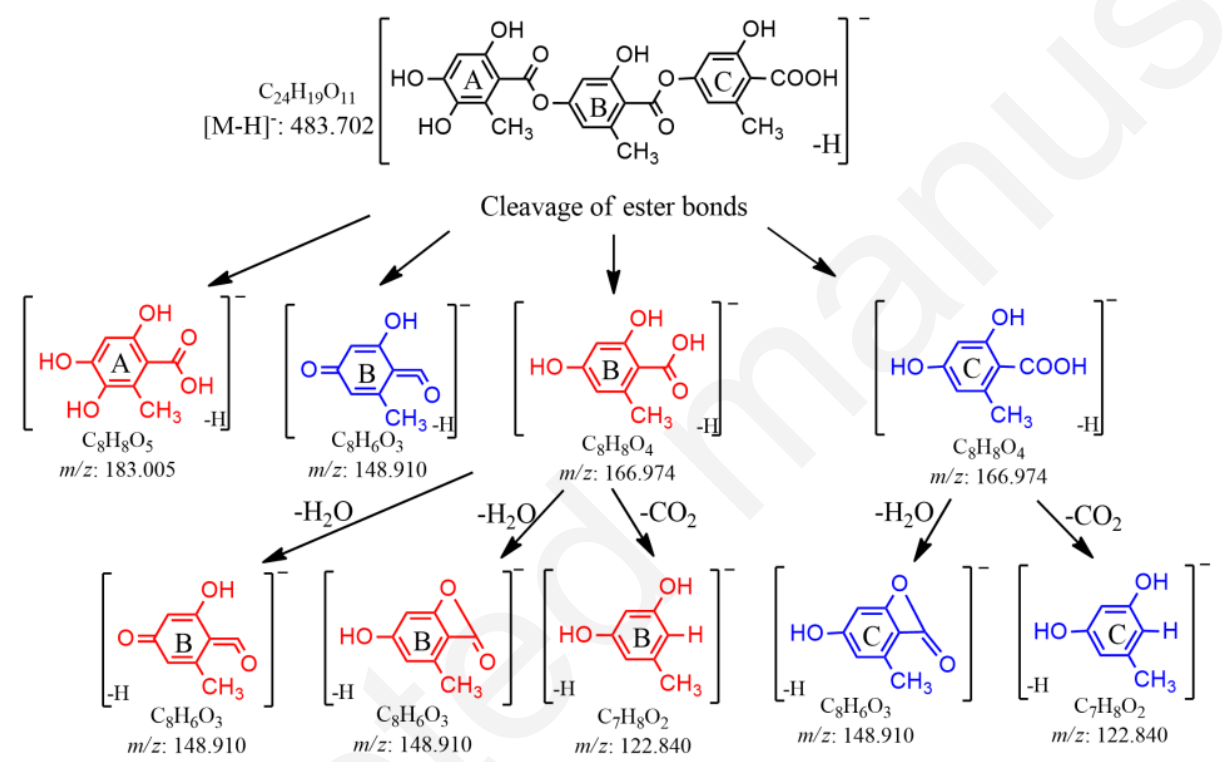

Fig 2 Proposed fragmentation scheme of hiascic acid 
$\mathrm{C}_{25} \mathrm{H}_{21} \mathrm{O}_{11}$

[M-H]": 497.736
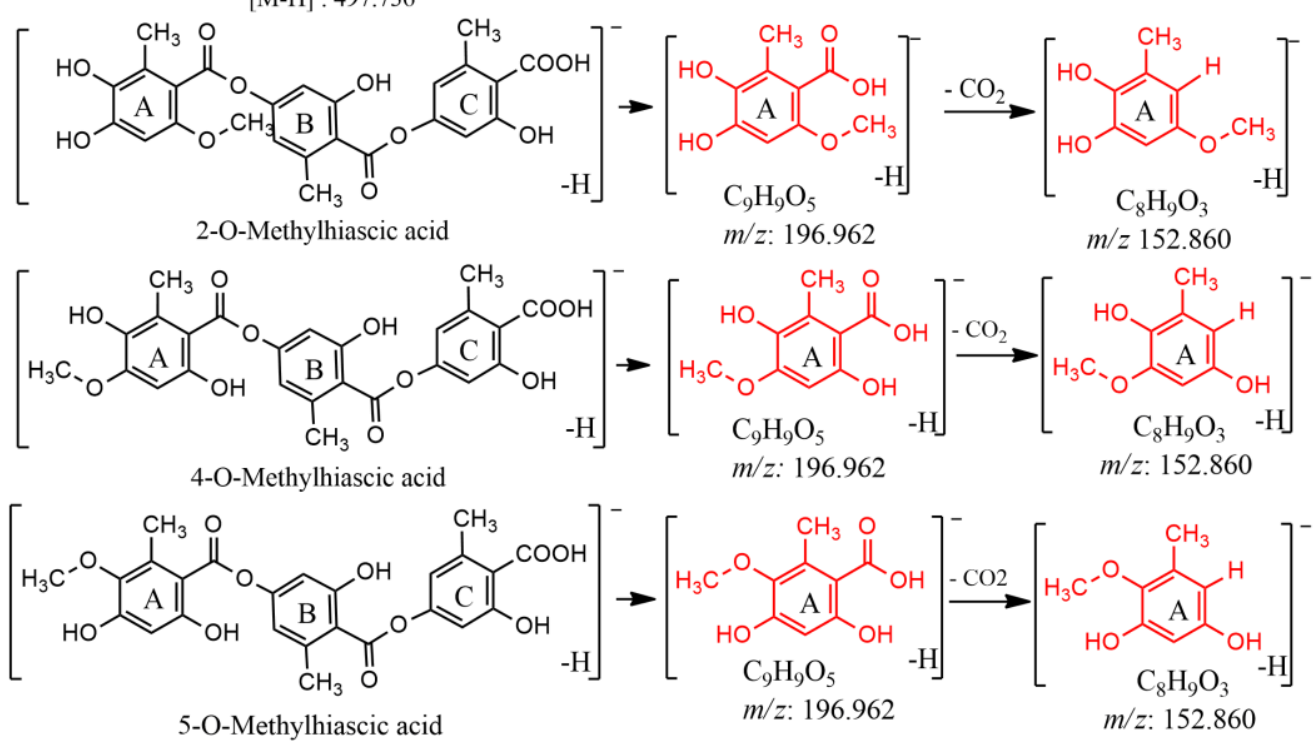
$\downarrow$ Cleavage of ester bond

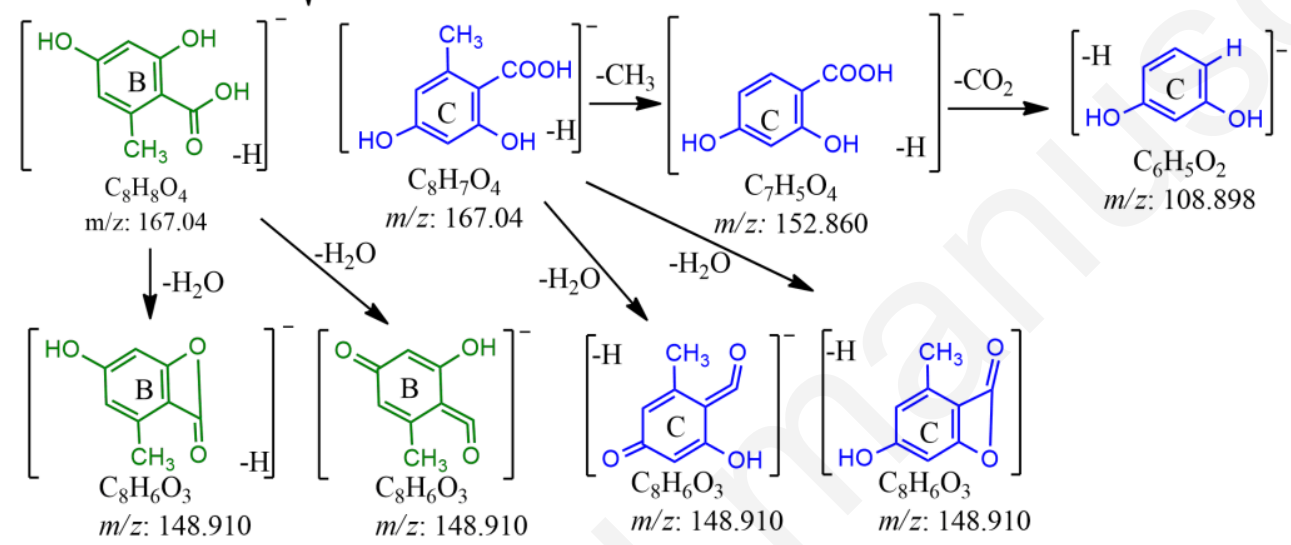

Fig 3 Proposed Fragmentation scheme of hiascic acid complex member

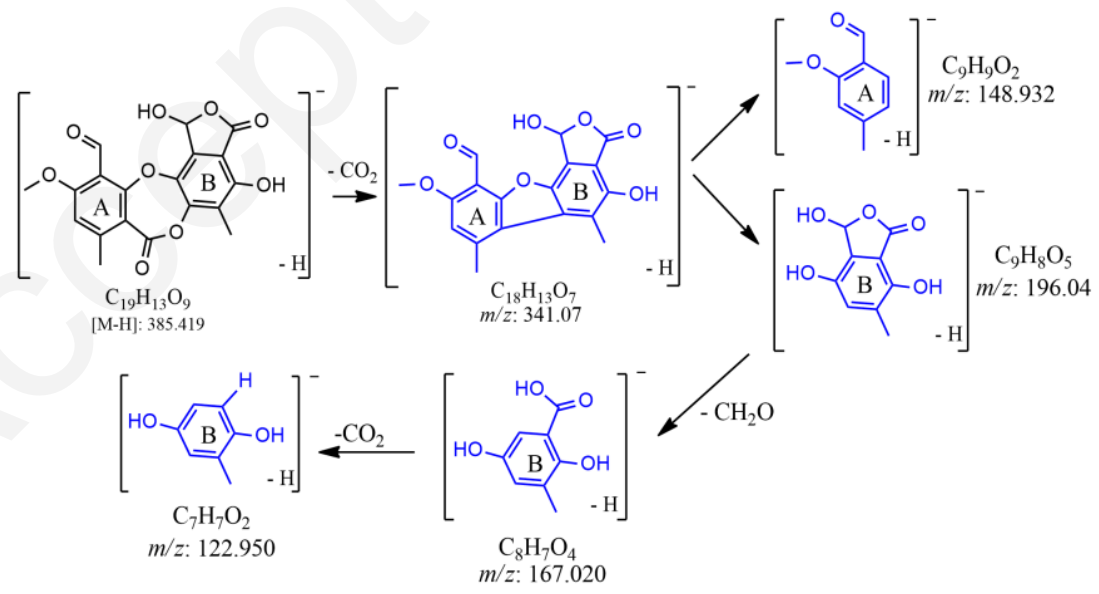

Fig 4 Proposed fragmentation scheme of stictic acid 


\begin{tabular}{|l|}
\hline Aspescts \\
\hline \hline Flat (-1) \\
\hline North (0-22.5) \\
Northeast (22.5-67.5) \\
East (67.5-112.5) \\
Southeast (112.5-157.5) \\
South (157.5-202.5) \\
Southwest (202.5-247.5) \\
West (247.5-292.5) \\
Northwest (292.5-337.5) \\
North (337.5-360) \\
\hline
\end{tabular}

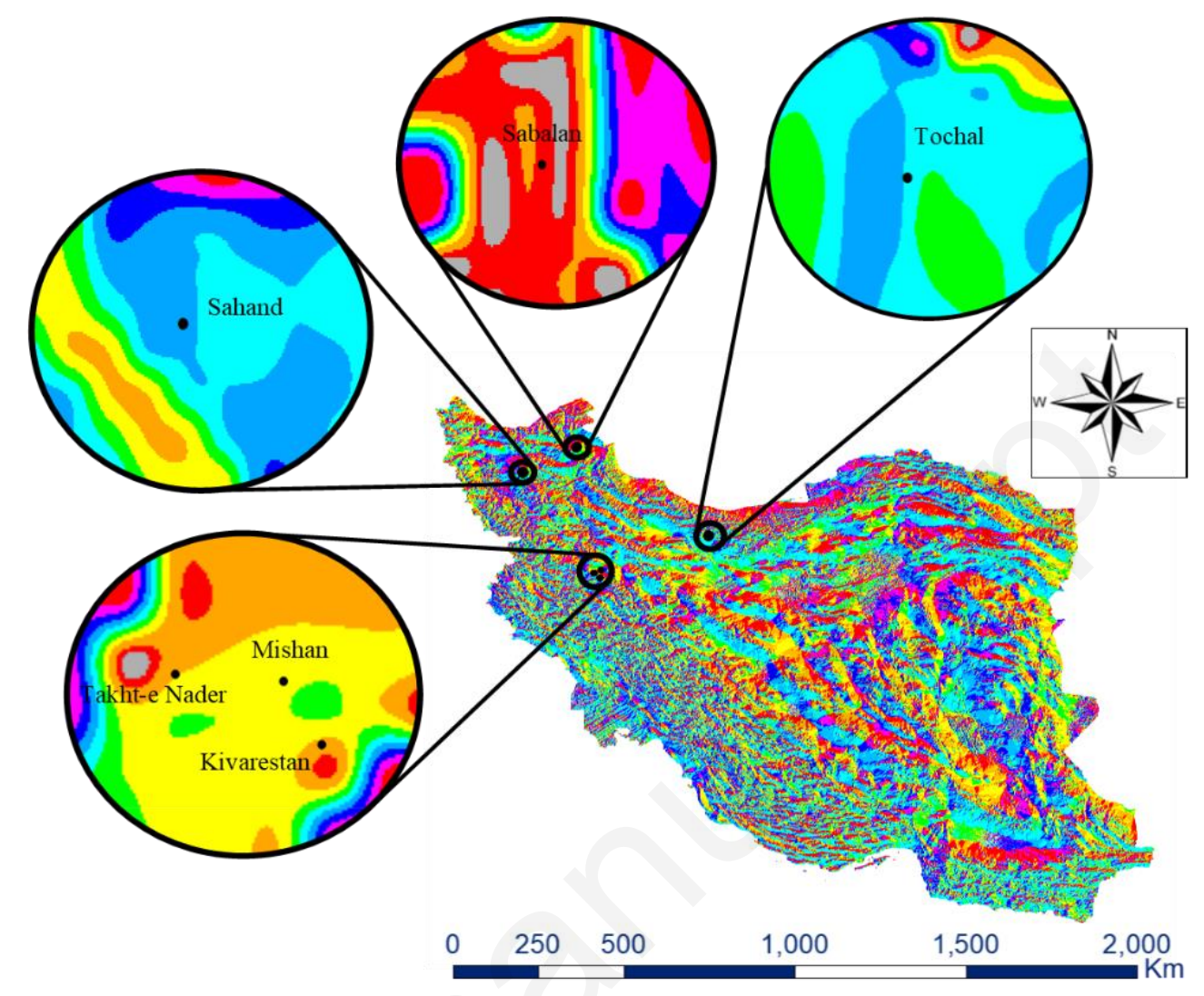

Fig 5 Aspect map of Iran and localities of investigated ecotypes 


\section{Table 2}

Characterization of major compounds from 6 U. aprina ecotypes identified using LC-ESI-MS/MS. $[\mathrm{M}-\mathrm{H}]^{-}: \mathrm{m} / z$ of the molecular ion; Rt (min): retention time for each compound; MS/MS ions (at $30 \mathrm{eV}$ ): product ions for each compound; (R.I. \%): relative intensities \%; Presence or absence of identified secondary metabolites in each $U$. aprina ecotype is indicated respectively by + and -

\begin{tabular}{|c|c|c|c|c|c|c|c|c|c|c|c|}
\hline \multirow{3}{*}{$\begin{array}{l}\text { Peak } \\
\text { no. }\end{array}$} & \multirow{3}{*}{$\begin{array}{l}\text { Molecular } \\
\text { formula }\end{array}$} & \multirow{3}{*}{$\begin{array}{l}{[\mathrm{M}-\mathrm{H}]^{-}} \\
m / z\end{array}$} & \multirow[t]{3}{*}{ Rt (min) } & \multirow[t]{3}{*}{ MS/MS ions $(m / z)$ at $30 \mathrm{eV}($ R.I. \%) } & \multirow[t]{3}{*}{ Identification } & \multicolumn{6}{|c|}{ Ecotypes } \\
\hline & & & & & & \multirow{2}{*}{ Kivarestan } & Takhte-e & Mishan & Tochal & Sabalan & Sahand \\
\hline & & & & & & & \multicolumn{5}{|l|}{ Nader } \\
\hline 1 & $\mathrm{C}_{8} \mathrm{H}_{7} \mathrm{O}_{4}$ & 167.210 & 14.72 & $81.385(100)$ & Orsellinic acid & + & + & + & + & + & + \\
\hline 2 & $\mathrm{C}_{19} \mathrm{H}_{13} \mathrm{O}_{9}$ & 385.419 & 14.78 & $167.020(100) / 148.932(30) / 122.950(25)$ & Stictic acid & + & + & - & + & - & + \\
\hline \multirow[t]{2}{*}{3} & \multirow[t]{2}{*}{$\mathrm{C}_{25} \mathrm{H}_{21} \mathrm{O}_{10}$} & \multirow[t]{2}{*}{481.646} & \multirow[t]{2}{*}{15.02} & $181.050(100) / 167.075(20) / 162.810$ & \multirow[t]{2}{*}{ Umbilicaric acid } & \multirow[t]{2}{*}{+} & \multirow[t]{2}{*}{+} & \multirow[t]{2}{*}{+} & \multirow[t]{2}{*}{+} & \multirow[t]{2}{*}{+} & \multirow[t]{2}{*}{+} \\
\hline & & & & $(40) / 148.882(25) / 136.950(30)$ & & & & & & & \\
\hline \multirow[t]{2}{*}{4} & \multirow[t]{2}{*}{$\mathrm{C}_{17} \mathrm{H}_{15} \mathrm{O}_{7}$} & \multirow[t]{2}{*}{331.398} & \multirow[t]{2}{*}{15.03} & $180.952(15) / 162.723(35) / 148.915(18) /$ & \multirow[t]{2}{*}{ Evernic acid } & \multirow[t]{2}{*}{-} & \multirow[t]{2}{*}{-} & \multirow[t]{2}{*}{+} & \multirow[t]{2}{*}{-} & \multirow[t]{2}{*}{-} & \multirow[t]{2}{*}{-} \\
\hline & & & & $136.915(100) / 104.848(25)$ & & & & & & & \\
\hline \multirow[t]{2}{*}{5} & \multirow[t]{2}{*}{$\mathrm{C}_{24} \mathrm{H}_{19} \mathrm{O}_{11}$} & \multirow[t]{2}{*}{483.702} & \multirow[t]{2}{*}{16.37} & $183.005(10) / 166.974(100) / 148.910$ & Hiascic acid & + & + & + & + & + & + \\
\hline & & & & $(10) / 122.840(5)$ & & & & & & & \\
\hline 6 & $\mathrm{C}_{25} \mathrm{H}_{21} \mathrm{O}_{11}$ & 497.736 & 16.56 & $196.96295) / 152.860(100) / 148.910$ & Hiascic acid & + & + & + & + & + & + \\
\hline & & & & $(30) / 108.898(10)$ & complex member & & & & & & \\
\hline 7 & - & 347.313 & 16.60 & $197.251(12) / 152.867(100) / 148.99230) /$ & Unknown & - & + & + & - & - & - \\
\hline & & & & $108.883(60)$ & & & & & & & \\
\hline 8 & $\mathrm{C}_{16} \mathrm{H}_{13} \mathrm{O}_{7}$ & 317.400 & 17.70 & $166.970(90) / 148.920(50) / 122.883(100)$ & Lecanoric acid & + & + & + & + & + & + \\
\hline 9 & $\mathrm{C}_{24} \mathrm{H}_{20} \mathrm{O}_{10}$ & 467.612 & 17.70 & $166.949(100) / 148.912(20) / 122.920(5)$ & Gyrophoric acid & + & + & + & + & + & + \\
\hline
\end{tabular}




\section{References}

Bjerke, W., Elvebakk, A., Domínguez, E., Dahlback, A., 2005. Seasonal trends in usnic acid concentrations of Arctic, alpine and Patagonian populations of the lichen Flavocetraria nivalis. Phytochemistry 66, 337-344. https://doi.org/10.1016/j.phytochem.2004.12.007

Bjerke, W., Zielke, M., Solheim, B., 2003. Long-term impacts of simulated climatic change on secondary metabolism, thallus structure and nitrogen fixation activity in two cyanolichens from the Arctic. New Phytologist 159, 361-367. https://doi.org/10.1046/j.1469-8137.2003.00812.x

Brakni, R., Ali Ahmed, M., Burger, P., Schwing, A., Michel, G., Pomares, C., Hasseine, L., Boyer, L., Fernandez, X., Landreau, A., Michel, T., 2018. UHPLC-HRMS/MS Based Profiling of Algerian Lichens and Their Antimicrobial Activities. Chemistry and Biodiversity 15, e1800031. https://doi.org/10.1002/cbdv.201800031

Castro, O.N., Benites, J., Rodilla, J., Santiago, J.C., Simirgiotis, M., Sepúlveda, B., Areche, C., 2017. Metabolomic Analysis of the Lichen Everniopsis trulla Using Ultra High Performance Liquid Chromatography-Quadrupole-Orbitrap Mass Spectrometry (UHPLC-Q-OT-MS). Chromatographia 80, 967-973. https://doi.org/10.1007/s10337017-3304-4

Clayden, S.R., 1992. Chemical divergence of eastern North American and European populations of Arctoparmelia centrifuga and their sympatric usnic acid-deficient chemotypes. Bryologist 1-4.

Cornejo, A., Salgado, F., Caballero, J., Vargas, R., Simirgiotis, M., Areche, C., 2016. Secondary metabolites in ramalina terebrata detected by UHPLC/ESI/MS/MS and identification of parietin as tau protein inhibitor. International Journal of Molecular Sciences 17, 1303. https://doi.org/10.3390/ijms17081303

Culberson, C.F., Culberson, W.L., Johnson, A., 1983. Genetic and environmental effects of growth and production of secondary compounds in Cladonia cristatella. Biochemical Systematics and Ecology 11, 77-84. https://doi.org/10.1016/0305-1978(83)90003-0

Culberson, W.L., 1967. Analysis of Chemical and Morphological Variation in the Ramalina siliquosa Species Complex. Brittonia 19, 333. https://doi.org/10.2307/2805533

Culberson, W.L., Culberson, C.F., Johnson, A., 1993. Speciation in lichens of the Ramalina siliquosa complex (Ascomycotina, Ramalinaceae): Gene flow and reproductive isolation. American Journal of Botany 80, 1472-1481. https://doi.org/10.2307/2445677

Fahselt, D., 2008. Individuals and populations of lichens, in: Lichen Biology, Second Edition. pp. 252-273. https://doi.org/10.1017/CBO9780511790478.014

Fahselt, D., BeGora, M., 2001. Usnic acid and atranorin concentrations in lichens in relation to bands of UV irradiance. Bryologist 104, 134-140. https://doi.org/10.1639/00072745(2001)104[0134:UAAACI]2.0.CO;2

Fernández-Moriano, C., Gómez-Serranillos, M.P., Crespo, A., 2016. Antioxidant potential of lichen species and their secondary metabolites. A systematic review. Pharmaceutical Biology. https://doi.org/10.3109/13880209.2014.1003354

Hamada, N., 1991. Environmental Factors Affecting the Content of Usnic Acid in the Lichen Mycobiont of Ramalina siliquosa. The Bryologist 94, 57-59.

Hamada, N., 1984. The Content of Lichen Substances in Ramalina Siliquosa Cultured at Various Temperatures in Growth Cabinets. The Lichenologist 16, 96-98. 
Hamada, N., 1982. The distribution pattern of the medullary depsidone salazinic acid in the thallus of Ramalina siliquosa (lichens). Canadian Journal of Botany 60, 379-382. https://doi.org/10.1139/b82-053

Hestmark, G., 1991. Teleomorph-anamorph relationships in umbilicaria II. Patterns in propagative morph production. The Lichenologist 23, 361-380. https://doi.org/10.1017/S0024282991000518

Jin, Y., Ma, Y., Xie, W., Hou, L., Xu, H., Zhang, K., Zhang, L., Du, Y., 2018. UHPLC-QTOF-MS/MS-oriented characteristic components dataset and multivariate statistical techniques for the holistic quality control of: Usnea. RSC Advances 8, 15487-15500. https://doi.org/10.1039/c8ra00081f

Krog, H., Swinscow, T.D.V., 1986. The lichen genera Lasallia and Umbilicaria in East Africa. Nordic Journal of Botany 6, 75-85. https://doi.org/10.1111/j.17561051.1986.tb00861.x

Krzewicka, B., 2004. The lichen genera Lasallia and Umbilicaria in the Polish Tatra Mts. Polish Botanical Studies 17, 1-88.

Krzewicka, B., Osyczka, P., 2002. Umbilicaria aprina Nyl. - A new lichen species from Central Europe. Acta Societatis Botanicorum Poloniae 71, 171-174. https://doi.org/10.5586/asbp.2002.020

Krzewicka, B., Smykla, J., 2004. The lichen genus Umbilicaria from the neighbourhood of Admiralty Bay (King George Island, maritime Antarctic), with a proposed new key to all Antarctic taxa. Polar Biology 28, 15-25. https://doi.org/10.1007/s00300-004-0638-9

Kumar, K., Siva, B., Sarma, V.U.M., Mohabe, S., Reddy, A.M., Boustie, J., Tiwari, A.K., Rao, N.R., Babu, K.S., 2018. UPLC-MS/MS quantitative analysis and structural fragmentation study of five Parmotrema lichens from the Eastern Ghats. Journal of Pharmaceutical and Biomedical Analysis 156, 45-57.

https://doi.org/10.1016/j.jpba.2018.04.017

Manojlović, N., Vasiljević, P., Maskovic, P.Z., Juskovic, M., Bogdanovic-Dusanovic, G., 2012. Chemical composition, antioxidant, and antimicrobial activities of lichen Umbilicaria cylindrica (L.) delise (Umbilicariaceae). Evidence-based Complementary and Alternative Medicine 2012. https://doi.org/10.1155/2012/452431

Matteucci, E., Occhipinti, A., Piervittori, R., Maffei, M.E., Favero-Longo, S.E., 2017. Morphological, Secondary Metabolite and ITS (rDNA) Variability within Usnic AcidContaining Lichen Thalli of Xanthoparmelia Explored at the Local Scale of Rock Outcrop in W-Alps. Chemistry and Biodiversity 14, e1600483. https://doi.org/10.1002/cbdv.201600483

Musharraf, S.G., Kanwal, N., Thadhani, V.M., Choudhary, I.M., 2015. Rapid identification of lichen compounds based on the structure-fragmentation relationship using ESIMS/MS analysis. Analytical Methods 7, 6066-6076. https://doi.org/10.1039/c5ay01091h

Musharraf, S.G., Siddiqi, F., Ali, A., Thadhani, V.M., 2017. Sensitive analysis of bioactive secondary metabolites in lichen species using liquid chromatography-mass spectrometry. Journal of Pharmaceutical and Biomedical Analysis 146, 279-284. https://doi.org/10.1016/j.jpba.2017.07.016

Narui, T., Culberson, C.F., Culberson, W.L., Johnson, A., Shibata, S., 1996. A Contribution to the Chemistry of the Lichen Family Umbilicariaceae (Ascomycotina). The Bryologist 
99, 199. https://doi.org/10.2307/3244550

Narui, T., Sawada, K., Takatsuki, S., Okuyama, T., Culberson, C.F., Culberson, W.L., Shibata, S., 1998. NMR assignments of depsides and tridepsides of the lichen family Umbilicariaceae. Phytochemistry 48, 815-822. https://doi.org/10.1016/S00319422(97)00958-8

Nguyen, K.H., Chollet-Krugler, M., Gouault, N., Tomasi, S., 2013. UV-protectant metabolites from lichens and their symbiotic partners. Natural Product Reports 30, 1490-1508. https://doi.org/10.1039/c3np70064j

Oettl, S.K., Hubert, J., Nuzillard, J.M., Stuppner, H., Renault, J.H., Rollinger, J.M., 2014. Dereplication of depsides from the lichen Pseudevernia furfuracea by centrifugal partition chromatography combined to $13 \mathrm{C}$ nuclear magnetic resonance pattern recognition. Analytica Chimica Acta 846, 60-67. https://doi.org/10.1016/j.aca.2014.07.009

Parrot, D., Jan, S., Baert, N., Guyot, S., Tomasi, S., 2013. Comparative metabolite profiling and chemical study of Ramalina siliquosa complex using LC-ESI-MS/MS approach. Phytochemistry 89, 114-124. https://doi.org/10.1016/j.phytochem.2013.02.002

Parrot, D., Peresse, T., Hitti, E., Carrie, D., Grube, M., Tomasi, S., 2015. Qualitative and spatial metabolite profiling of Lichens by a LC-MS approach combined with optimised extraction. Phytochemical Analysis 26, 23-33. https://doi.org/10.1002/pca.2532

Piercey-Normore, M.D., 2007. The genus Cladonia in Manitoba: Exploring taxonomic trends with secondary metabolites. Mycotaxon 101, 189-199.

Piercey-Normore, M.D., 2003. A field survey of the genus Cladonia (Ascomycotina) in Manitoba, Canada. Mycotaxon 86, 233-247.

Poelt, J., Nash, T., 2006. Studies in the Umbilicaria vellea Group (Umbilicariaceae) in North America. The Bryologist 96, 422. https://doi.org/10.2307/3243872

Posner, B., Feige, G.B., Huneck, S., 1992. Studies on the chemistry of the lichen genus umbilicaria hoffm. Zeitschrift fur Naturforschung 47, 1-9. https://doi.org/10.1515/znc1992-1-202

Ranković, B., 2015. Lichen secondary metabolites: Bioactive properties and pharmaceutical potential. Lichen Secondary Metabolites: Bioactive Properties and Pharmaceutical Potential 1-202. https://doi.org/10.1007/978-3-319-13374-4

Ranković, B., Kosanić, M., 2015. Lichens as a potential source of bioactive secondary metabolites, in: Lichen Secondary Metabolites: Bioactive Properties and Pharmaceutical Potential. Springer International Publishing, Cham, pp. 1-26. https://doi.org/10.1007/978-3-319-13374-4_1

Rubio, C., Fernández, E., Hidalgo, M.E., Quilhot, W., 2009. Effects of Solar Uv-B Radiation in the Accumulation of Rhizocarpic Acid in a Lichen Species From Alpine Zones of Chile. Boletín de la Sociedad Chilena de Química 47, 67-72. https://doi.org/10.4067/s0366-16442002000100012

Salgado, F., Albornoz, L., Cortéz, C., Stashenko, E., Urrea-Vallejo, K., Nagles, E., GaliciaVirviescas, C., Cornejo, A., Ardiles, A., Simirgiotis, M., García-Beltrán, O., Areche, C., 2018. Secondary metabolite profiling of species of the genus usnea by UHPLC-ESI-OTMS-MS. Molecules 23, 54. https://doi.org/10.3390/molecules23010054

Serina, E., Arroyo, R., Manrique, E., Sancho, L.G., 1996. Lichen substances and their 
intraspecifie variability within eleven Umbilicaria species in spain. The Bryologist 99, 335-342. https://doi.org/10.2307/3244307

Shukla, V., Patel, D.K., Bajpai, R., Semwal, M., Upreti, D.K., 2016. Ecological implication of variation in the secondary metabolites in Parmelioid lichens with respect to altitude. Environmental Science and Pollution Research 23, 1391-1397. https://doi.org/10.1007/s11356-015-5311-z

Swanson, A., Fahselt, D., Smith, D., 1996. Phenolic levels in Umbilicaria americana in relation to enzyme polymorphism, altitude and sampling date. Lichenologist 28, 331339. https://doi.org/10.1006/lich.1996.0030

Torres-Benítez, A., Rivera-Montalvo, M., Sepúlveda, B., Castro, O.N., Nagles, E., Simirgiotis, M., García-Beltrán, O., Areche, C., 2017. Metabolomic Analysis of Two Parmotrema Lichens: P. robustum (Degel.) Hale and P. andinum (Mull. rg.) Hale Using UHPLC-ESI-OT-MS-MS. Molecules 22, 1861.

https://doi.org/10.3390/molecules22111861

Upreti, D.K., Pant, G., 2008. Lichen Flora in and Around Maitri Region , Schirmacher Oasis , East Antarctica 229-241.

Xu, M., Heidmarsson, S., Thorsteinsdottir, M., Eiriksson, F.F., Omarsdottir, S., Olafsdottir, E.S., 2017. DNA barcoding and LC-MS metabolite profiling of the lichen-forming genus Melanelia: Specimen identification and discrimination focusing on Icelandic taxa. Plos One 12, e0178012. https://doi.org/10.1371/journal.pone.0178012

Zlatanović, I., Zrnzević, I., Jovanovic, O., Stojanović, I., Petrovic, G., Stojanovic, G., 2017. Chemical composition of umbilicaria crustulosa and U. cylindrica. Natural Product Communications 12, 1105-1106. 